\title{
A Bio-Based Alginate Aerogel as an Ionic Liquid Support for the Efficient Synthesis of Cyclic Carbonates from $\mathrm{CO}_{2}$ and Epoxides
}

\author{
Ana B. Paninho 1,2, Ana N. Mustapa 2,3, Kamran T. Mahmudov 4 , Armando J. L. Pombeiro ${ }^{4}$ (D), \\ M. Fátima C. Guedes da Silva ${ }^{4}$ (D), María D. Bermejo ${ }^{2}{ }^{(D)}$, Ángel Martín ${ }^{2}$, María J. Cocero ${ }^{2}$ and Ana V. M. Nunes ${ }^{1, *}$ \\ 1 LAQV, REQUIMTE, Departamento de Química, Faculdade de Ciências e Tecnologia, Universidade Nova de \\ Lisboa, 2829-516 Caparica, Portugal; anapaninho@gmail.com \\ 2 High Pressure Processes Group, Industrial Engineering School, Department of Chemical Engineering and \\ Environmental Technology, University of Valladolid, C/Dr. Mergelina, s/n, 47011 Valladolid, Spain; \\ anajwa@uitm.edu.my (A.N.M.); mdbermejo@iq.uva.es (M.D.B.); mamaan@iq.uva.es (Á.M.); \\ mjcocero@iq.uva.es (M.J.C.) \\ 3 School of Chemical Engineering, College of Engineering, Universiti Teknologi MARA (UiTM), \\ Shah Alam 40450, Selangor, Malaysia \\ 4 Centro de Química Estrutural, Instituto Superior Técnico, Universidade de Lisboa, Av. Rovisco Pais, \\ 1049-001 Lisbon, Portugal; kamran.mahmudov@tecnico.ulisboa.pt (K.T.M.); \\ pombeiro@tecnico.ulisboa.pt (A.J.L.P.); fatima.guedes@tecnico.ulisboa.pt (M.F.C.G.d.S.) \\ * Correspondence: ana.nunes@fct.unl.pt
}

\section{check for} updates

Citation: Paninho, A.B.; Mustapa, A.N.; Mahmudov, K.T.; Pombeiro, A.J.L.; Guedes da Silva, M.F.C.; Bermejo, M.D.; Martín, Á.; Cocero, M.J.; Nunes, A.V.M. A Bio-Based Alginate Aerogel as an Ionic Liquid Support for the Efficient Synthesis of Cyclic Carbonates from $\mathrm{CO}_{2}$ and Epoxides. Catalysts 2021, 11, 872. https://doi.org/10.3390/catal11080872

Academic Editor: Catia Cannilla

Received: 9 June 2021

Accepted: 9 July 2021

Published: 21 July 2021

Publisher's Note: MDPI stays neutral with regard to jurisdictional claims in published maps and institutional affiliations.

Copyright: (c) 2021 by the authors. Licensee MDPI, Basel, Switzerland. This article is an open access article distributed under the terms and conditions of the Creative Commons Attribution (CC BY) license (https:/ / creativecommons.org/licenses/by/ $4.0 /)$.

\begin{abstract}
In this work, the ionic liquid [Aliquat][Cl] was supported into alginate and silica aerogel matrices and applied as a catalyst in the cycloaddition reaction between $\mathrm{CO}_{2}$ and a bio-based epoxide (limonene oxide). The efficiency of the alginate aerogel system is much higher than that of the silica one. The method of wet impregnation was used for the impregnation of the aerogel with [Aliquat][Cl] and a zinc complex. The procedure originated a well-defined thin solvent film on the surface of support materials. Final materials were characterised by Fourier Transform Infrared Spectroscopy, $\mathrm{N}_{2}$ Adsorption-Desorption Analysis, X-ray diffraction, atomic absorption and Field Emission Scanning Microscopy. Several catalytic tests were performed in a high-pressure apparatus at $353.2 \mathrm{~K}$ and $4 \mathrm{MPa}$ of $\mathrm{CO}_{2}$.
\end{abstract}

Keywords: cyclic carbonates; $\mathrm{CO}_{2}$; epoxides; cycloaddition; alginate aerogels; supercritical; supported ionic liquids; limonene carbonate

\section{Introduction}

The utilization of $\mathrm{CO}_{2}$ as starting material to produce cyclic carbonates is a very active field of research. Cyclic carbonates are particularly attractive as intermediate $\mathrm{CO}_{2}$ derivatives since they can be formed readily from the catalytic coupling reaction between $\mathrm{CO}_{2}$ and the corresponding epoxide [1-3]. Furthermore, cyclic carbonates are broadly used as polar aprotic solvents, fuel additives, electrolytes for lithium-ion batteries, fine chemicals intermediates as well as monomers in polymerization reactions [4]. Binary catalytic systems composed of homogeneous metal complexes together with ionic liquids have been successfully used [5-7]. Several mechanistic studies showed that the ionic liquid plays a crucial role in the reaction kinetics, with the anion being responsible for the nucleophilic attack to the epoxide ring, which is the rate-determining step [8-11]. Recently, [Aliquat][Cl] was used both as catalyst and solvent in the cycloaddition reaction between $\mathrm{CO}_{2}$ and propylene oxide at high pressures [12].

The combination of high-pressure $\mathrm{CO}_{2}$ with ionic liquids originates an efficient biphasic system to carry out liquid phase catalysis. The fact that ionic liquids are practically insoluble in $\mathrm{CO}_{2}$, while $\mathrm{CO}_{2}$ presents high solubility in several types of these organic salts, 
allows to use $\mathrm{CO}_{2}$ as a mobile phase to transport reactants in and out of the ionic liquid phase, where homogeneous catalysts are dissolved [13]. Furthermore, besides negligible vapour pressure, one of the most remarkable features of ionic liquids is their tuneable solvent power, through the possibility to "design" its physicochemical properties by changing the anion/cation pair [14].

In this context, several authors have explored their utilization covalently attached or physically adsorbed onto solid materials suitable for fixed bed operations [15]. This approach is also known as Supported Ionic Liquid Phase (SILP) catalysis [16]. The concept involves dissolving a homogeneous catalyst in an ionic liquid that is further immobilized on the surface of a solid support, bringing together advantages of both homogeneous (high rates and good selectivity) and heterogeneous catalysis (easy separation, recyclability and continuous operation) [17]. Furthermore, SILP catalysis allows the usage of significantly lower amounts of ionic liquid, considerable reducing the diffusion pathway when compared to bulk biphasic systems, avoiding mass transport limitations and thereby leading to high reaction rates [18]. Over the last decade, SILPs have been used as functional materials and media, namely in catalysis and electrochemistry, in separation processes and as surface modifying agents [19].

Regarding SILP preparation methods, the ionic liquid can be chemically bond or simply physically adsorbed on the surface of a porous support material. When the ionic liquid is covalently bound to the support, the chemical bonding may limit the degree of freedom of the cation/anion or even change some properties of the ionic liquid as its solvation strength. Nevertheless, a notorious advantage is the minimization (or even elimination) of the highly undesirable phenomena of leakage of the ionic liquid layer into the reaction mixture. On the other hand, when a layer of ionic liquid is adsorbed at the surface of a porous support material, it is possible to take advantage of full bulk properties of the ionic liquid. Physisorption stands as the most simple and straightforward method of preparation, but the ionic liquid is more susceptible to leaching during the catalytic process, especially when polar substrates are used. That's the reason why, in practice, applications of physical adsorbed SILP materials are mostly limited to gas-phase operations.

Additionally, a variety of support materials [20] has been used, as graphene oxide [21], alumina [22], titania [22], molecular sieves [23], metal organic frameworks (MOFs) [24], organic polymers [25] and poly-ionic liquids [26,27]. Silica is by far the most explored material for the cycloaddition reaction between $\mathrm{CO}_{2}$ and epoxides [28-32]. Sakakura and co-workers reported that silica-supported onium salts achieved much higher catalytic activities compared to onium salts alone [33]. In these reactions, the cooperative action of the silanol groups and the nucleophile are responsible for the oxygen atom coordination and the nucleophilic ring opening of the epoxide, respectively [34]. Similar results were reported by Takashi Sakai et al. [35]. In this last work, it was also found that the pore size of the material affected the reaction kinetics, with materials bearing a pore size of $19 \mathrm{~nm}$ exhibiting much better performance when compared to silica materials bearing a mean pore size of $6 \mathrm{~nm}$.

The utilization of biopolymers as ionic liquids supports is a very attractive strategy since biopolymer sources are well established, are relatively cheap and accessible at industrial scale. However, to the best of our knowledge, for the cycloaddition reaction between $\mathrm{CO}_{2}$ and epoxides, their use is still limited to cellulose derivatives and chitosan [36-38].

On the context of our interest in developing greener approaches for $\mathrm{CO}_{2}$ conversion into organic carbonates [39], in this work, we have supported an ionic liquid ([Aliquat][Cl]) into an alginate aerogel matrix and applied it as SILP catalyst for the cycloaddition reaction between $\mathrm{CO}_{2}$ and limonene oxide (a bio-based epoxide). The use of epoxides derived from renewable resources such as waste biomass has recently received increasing attention as a strategy to produce fully sustainable cyclic carbonates [40-42]. In particular, limonene epoxide has been explored in several studies as a renewable substrate that is also particularly challenging due to intrinsically higher steric demand [43,44]. 
The biopolymer alginate is naturally derived from the seaweed brown algae and is composed with $\alpha$-L-guluronic acid and $\beta$-D-mannuronic acid blocks, linearly linked by 1,4-glycosidic linkage. Due to its biodegradability, low cost, non-toxicity and stability, it is an attractive candidate for SILP preparation and application in carbonates production [45].

\section{Results and Discussion}

The preparation and impregnation methods carried out for silica (SIL) and alginate (ALG) aerogels with the zinc complex $(\mathrm{Zn})$ and/or the ionic liquid [Aliquat][Cl] (IL) are summarized in Table 1. The zinc complex used in this work was synthesized and extensively characterised in a previously work [46,47].

Table 1. Impregnated silica (SIL) and alginate (ALG) aerogels prepared by the wet impregnation method.

\begin{tabular}{ccc}
\hline Matrix & Material Reference & Substance Impregnated \\
\hline \multirow{2}{*}{ Silica } & Zn-SIL1 & Zn(II)-AHBD \\
& Zn-SIL2 & Zn(II)-AHBD \\
& Zn-IL-SIL2 & Zn(II)-AHBD + IL \\
\hline \multirow{2}{*}{ Alginate } & Zn-ALG & Zn(II)-AHBD \\
& Zn-IL-ALG & Zn(II)-AHBD + IL \\
& IL-ALG & IL \\
\hline
\end{tabular}

\subsection{Infrared Spectroscopy Studies}

Figures 1-3 show the results of FTIR assays for the impregnated alginate and silica aerogels in comparison with blank aerogels, pure Zn(II)-AHBD catalyst and pure [Aliquat][Cl]. The y-axis scale is the same for all curves. The corresponding absorption bands of the $\mathrm{Zn}$ (II)-AHBD catalyst were not observed clearly in the impregnated samples, which can indicate that only a low amount was impregnated into the aerogels. For the blank alginate aerogel (Figure 1, ALG), it is possible to observe several characteristic absorption bands at $3450 \mathrm{~cm}^{-1}\left(\mathrm{O}-\mathrm{H}\right.$ stretching) and the alginic acid bands between 700 and $1800 \mathrm{~cm}^{-1}$ [48].

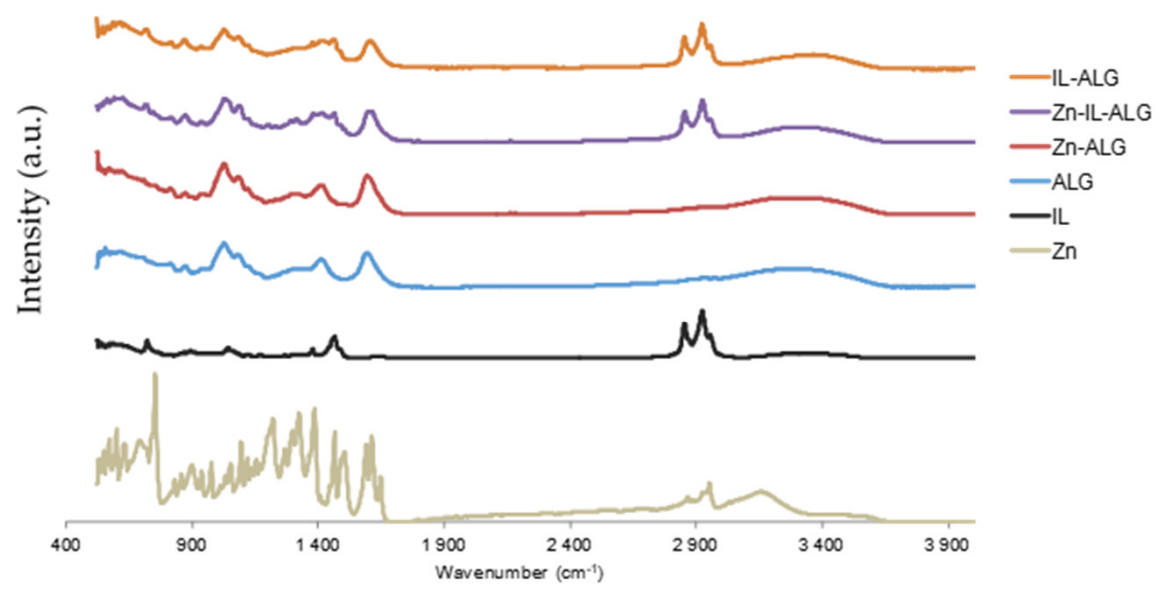

Figure 1. Infrared spectra of pure $\mathrm{Zn}(\mathrm{II})-\mathrm{AHBD}$ catalyst $(\mathrm{Zn})$, pure [Aliquat][Cl] (IL) and alginate aerogels: blank alginate aerogel (ALG), Zn(II)-AHBD-impregnated aerogel (Zn-ALG), aerogel impregnated with $\mathrm{Zn}(\mathrm{II})-\mathrm{AHBD}$ and [Aliquat][Cl] (Zn-IL-ALG) and aerogel impregnated with [Aliquat][Cl] (IL-ALG).

The corresponding absorption bands of pure [Aliquat][Cl] (Figure 1, IL) can be seen at $1480 \mathrm{~cm}^{-1}$ (CH2 blending) and between 2800 and $3000 \mathrm{~cm}^{-1}$ (C-H stretching) [49]. The obtained spectrum of pure [Aliquat][Cl] was compared with the [Aliquat][Cl]-impregnated alginate aerogels (Figure 1, Zn-IL-ALG and IL-ALG) and it was observed that [Aliquat][Cl] 
characteristic peaks also appeared in the spectrum, which indicates that [Aliquat][Cl] was successfully impregnated into the alginate aerogels. A similar behaviour of the $\mathrm{Zn}$ (II)$\mathrm{AHBD}+[$ Aliquat][Cl]-impregnated silica aerogels was observed, as shown in Figure 2 (Silica SIL2).

In this case, it was also possible to observe the [Aliquat][Cl] characteristic peaks in the spectrum. In comparison with alginate aerogel, the silica aerogel SIL2 had weaker absorption bands at $1480 \mathrm{~cm}^{-1}$ and between 2800 and $3000 \mathrm{~cm}^{-1}$, which indicates a lower [Aliquat][Cl] loading. For the sample Silica SIL1 (Figure 3), the characteristic peaks of the $\mathrm{Zn}$ (II)-AHBD catalyst were not observed, which may indicate that this impregnation was not so successful as the previous ones. Furthermore, silica aerogels presented a highly fragile structure and were not used in high pressure catalytic tests.

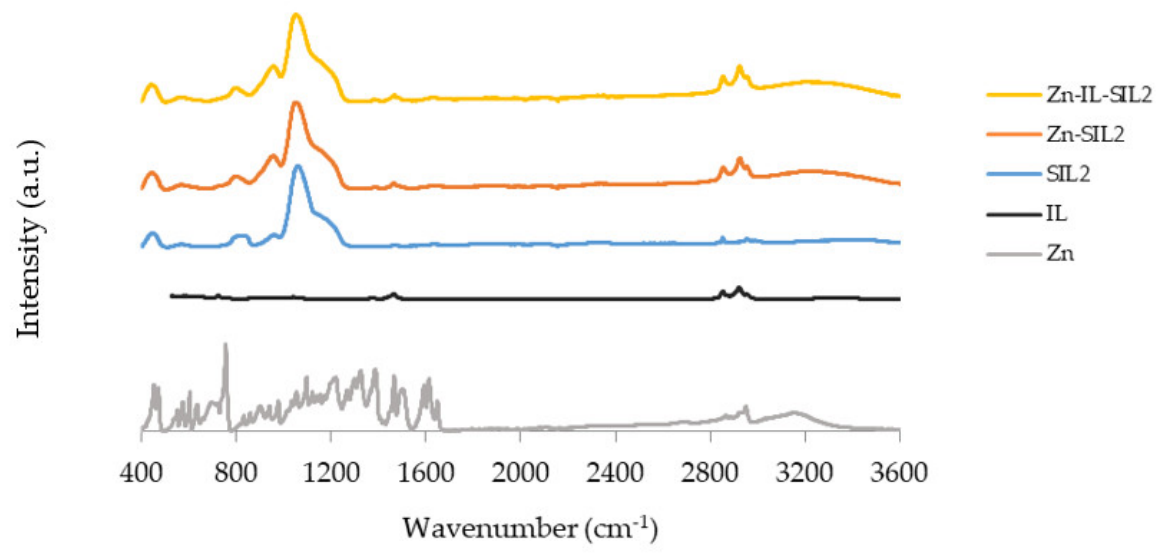

Figure 2. Infrared spectra of pure $\mathrm{Zn}(\mathrm{II})$-AHBD catalyst (Zn), pure [Aliquat][Cl] (IL) and silica aerogels: blank silica aerogel (SIL2), Zn(II)-AHBD-impregnated aerogel (Zn-SIL2) and aerogel impregnated with Zn(II)-AHBD and [Aliquat][Cl] (Zn-IL-SIL2).

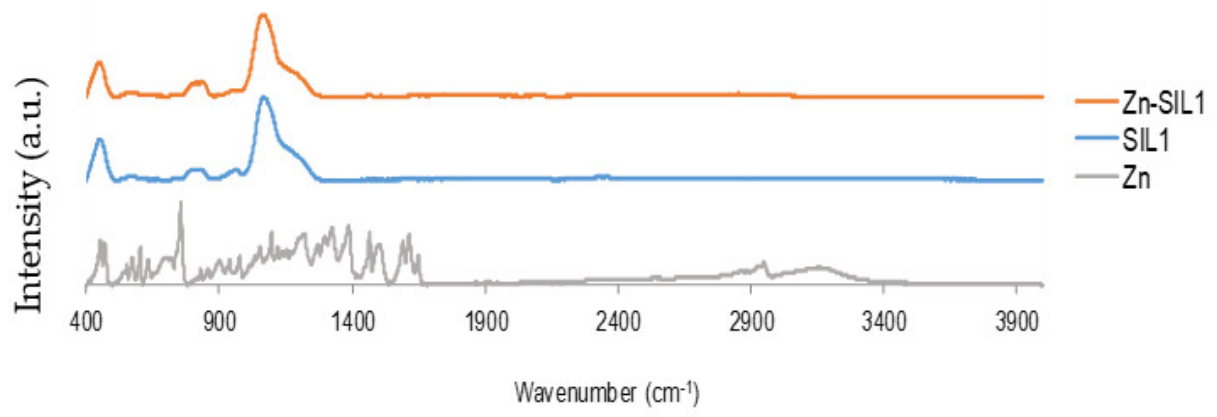

Figure 3. Infrared spectra of pure $\mathrm{Zn}(\mathrm{II})$-AHBD catalyst $(\mathrm{Zn})$ and silica aerogels: blank silica aerogel (SIL1) and Zn(II)-AHBD-impregnated aerogel (Zn-SIL1).

From the FTIR results presented in Figure 3, the Zn(II)-AHBD impregnation efficiency was difficult to evaluate. In fact, due to the complexity of the catalyst structure (Figure 4), the absorption bands appear overlapping and less defined. This hampers the FTIR analysis of $\mathrm{Zn}(\mathrm{II})$-AHBD content in the aerogels and prompted us to use atomic absorption technique. 


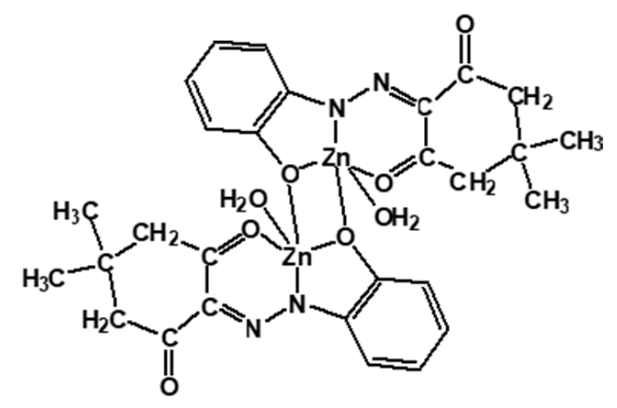

Figure 4. $\mathrm{Zn}(\mathrm{II})$-AHBD catalyst (zinc(II) complex of an arylhydrazone of a $\beta$-diketone).

\subsection{Nitrogen Physisorption Studies}

Table 2 shows the textural properties of blank and impregnated alginate and silica aerogels. Regarding results obtained for blank aerogels (not impregnated), it was possible to observe that silica aerogels presented a higher surface area and lower pore diameter than alginate aerogels, which is in accordance with results reported by other authors [50]. This difference in pores diameter is regarded as the basis of a lower impregnation efficiency into silica matrices [35].

Table 2. Textural properties of blank and impregnated silica (SIL) and alginate (ALG) aerogels. Aerogels were impregnated with the zinc complex ( $\mathrm{Zn}$ ) and/or the ionic liquid [Aliquat][Cl] (IL).

\begin{tabular}{|c|c|c|c|c|c|}
\hline Matrix & $\begin{array}{c}\text { Aerogel } \\
\text { Reference }\end{array}$ & Impregnation a & $S_{\text {BET }}\left(\mathrm{m}^{2} / \mathrm{g}\right)$ & $\begin{array}{l}\text { Pore Volume } \\
\qquad\left(\mathrm{cm}^{3} / \mathrm{g}\right)\end{array}$ & $\begin{array}{l}\text { Pore Diameter } \\
(\mathrm{nm})\end{array}$ \\
\hline \multirow{5}{*}{ Silica } & SIL1 & - & 882 & 2.85 & 12.93 \\
\hline & Zn-SIL1 & $\mathrm{Zn}(\mathrm{II})-\mathrm{AHBD}$ & 772 & 2.96 & 15.35 \\
\hline & SIL2 & - & 1099 & 2.44 & 8.91 \\
\hline & Zn-SIL2 & $\mathrm{Zn}(\mathrm{II})-\mathrm{AHBD}$ & 258 & 0.475 & 7.36 \\
\hline & Zn-IL-SIL2 & $\mathrm{Zn}(\mathrm{II})-\mathrm{AHBD}+\mathrm{IL}$ & 245 & 0.445 & 7.25 \\
\hline \multirow{4}{*}{ Alginate } & ALG & - & 271 & 2.27 & 33.56 \\
\hline & Zn-ALG & $\mathrm{Zn}(\mathrm{II})-\mathrm{AHBD}$ & 253 & 2.18 & 34.46 \\
\hline & Zn-IL-ALG & $\mathrm{Zn}(\mathrm{II})-\mathrm{AHBD}+\mathrm{IL}$ & $<1$ & - & - \\
\hline & IL-ALG & IL & $<1$ & - & - \\
\hline
\end{tabular}

a The ionic liquid used for impregnation was always [Aliquat][Cl].

When the aerogels were impregnated with $\mathrm{Zn}(\mathrm{II})-\mathrm{AHBD}$, a decrease (usually slight but pronounced in the case of SIL2) of the specific surface area was observed. On the other hand, when impregnated with the ionic liquid ([Aliquat][Cl]), which is an organic salt liquid at room temperature, the aerogel pores were totally filled, with consequent drastic decrease in the surface areas and pore volumes. This effect is more pronounced for alginate aerogels, especially the ones that were impregnated with [Aliquat][Cl], for which the BET surface area results were always lower than $1 \mathrm{~m}^{2} / \mathrm{g}$. Also, the alginate aerogel impregnated with both [Aliquat][Cl] and $\mathrm{Zn}(\mathrm{II})-\mathrm{AHBD}$ presented a BET surface area lower than $1 \mathrm{~m}^{2} / \mathrm{g}$.

In the case of silica aerogels this effect was not so evident, very likely due to the fact that the impregnation was less efficient. As a complement to the results reported in the Table 2, Figure 5 shows the nitrogen adsorption isotherms of the blank and impregnate alginate and silica aerogels. The isotherms belong to "type IV" which is typical for mesoporous materials. When the impregnation was performed with [Aliquat][Cl] (Zn-IL-ALG and IL-ALG, Figure 5) there is no desorption of N2 from the aerogels, which is in accordance with the BET surface results. 


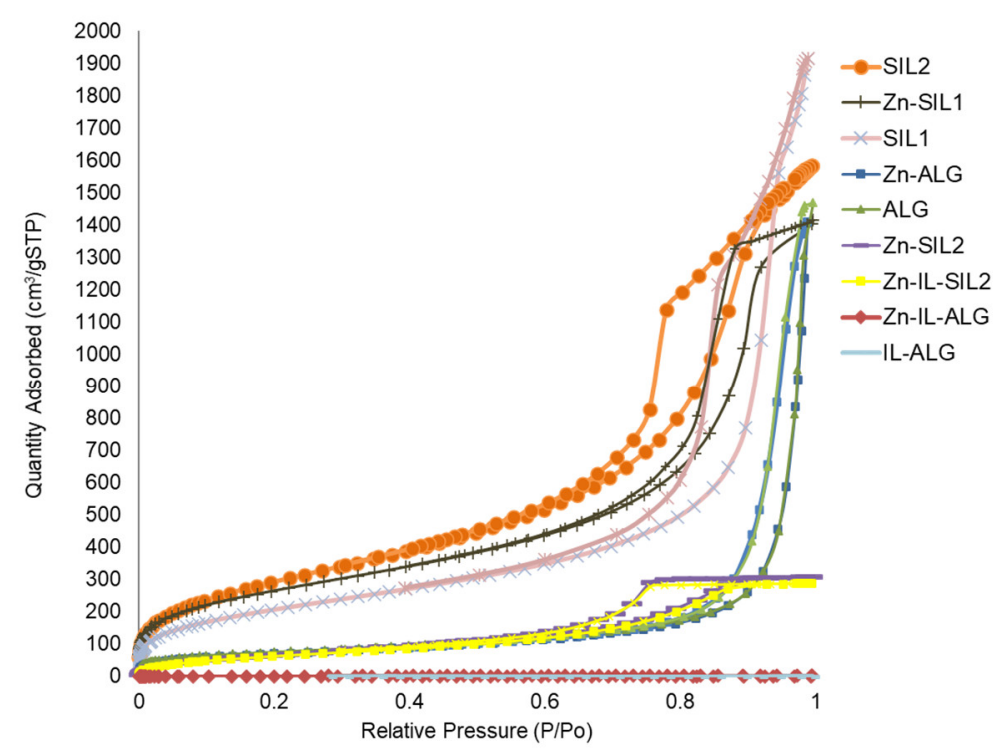

Figure 5. Nitrogen adsorption isotherms of the alginate and silica aerogels.

\subsection{Powder X-ray Diffraction Studies}

$X$-ray diffraction patterns for silica and alginate aerogels are shown in the Figures 6 and 7, respectively. Since this technique detects the crystallinity of the impregnated $\mathrm{Zn}(\mathrm{II})-\mathrm{AHBD}$ particles, the aerogels containing only [Aliquat][Cl] were not analysed by this technique. The X-ray diffraction patterns for blank silica aerogels (SIL1 and SIL2) and Zn(II)-AHBD impregnated silica aerogels (Zn-SIL1 and Zn-SIL2) are represented in the Figure 6. No changes on crystallinity of impregnated silica aerogels were observed. Therefore, the discussions on the effect of impregnation on surface morphology will be focused only in the alginate aerogels.

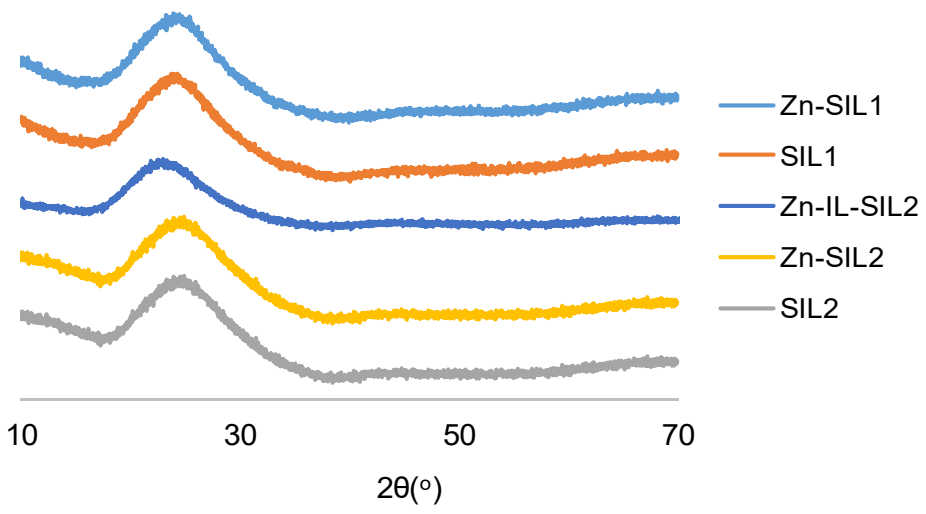

Figure 6. X-ray diffraction patterns of Zn(II)-AHBD-impregnated silica aerogels and blank silica aerogels.

The diffractogram of alginate is known to consist of two crystalline peaks around 14 and $23^{\circ}$ of $2 \theta$ which are related to the lateral packing among molecular chains and the layer spacing along the molecular chain direction, respectively [51,52]. For the blank alginate aerogel (Figure 7, ALG) it was possible to observe several characteristic diffraction peaks; the most intense are $23.3^{\circ}, 29.6^{\circ}, 35.9^{\circ}, 39.4^{\circ}, 42.9^{\circ}, 47.1^{\circ}$ and $48.4^{\circ}$. There are two evident typical diffraction peaks of pure Zn(II)-AHBD catalyst (Figure 7, Zn) that can be detected at $7.7^{\circ}$ and $25.1^{\circ}$. The spectrum of pure $\mathrm{Zn}(\mathrm{II})$-AHBD was compared with those of the impregnated aerogels (Figure 7, Zn-ALG) and it was possible to observe that the Zn(II)AHBD characteristic peaks appeared. This result indicates that although in low amounts, the $\mathrm{Zn}(\mathrm{II})$-AHBD complex was successfully impregnated into the alginate aerogels. 

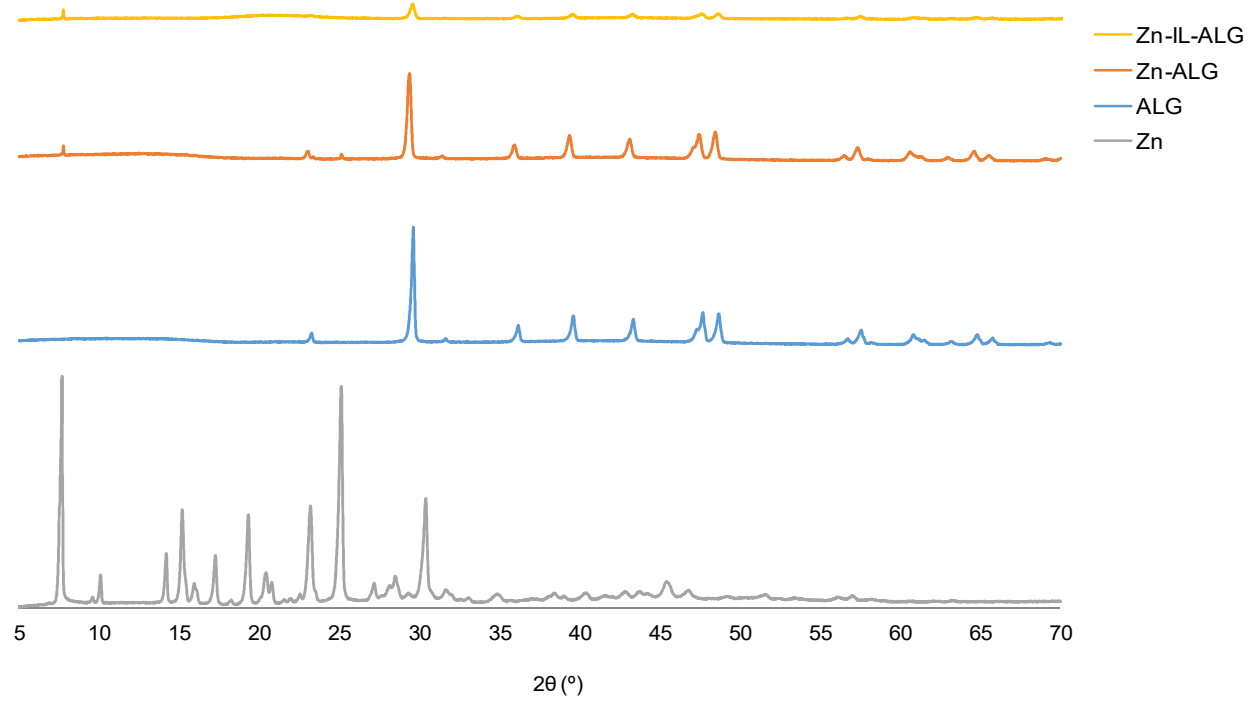

Figure 7. X-ray diffraction patterns of Zn(II)-AHBD- and [Aliquat][Cl]-impregnated alginate aerogels (Zn-IL-ALG), $\mathrm{Zn}(\mathrm{II})$-AHBD-impregnated alginate aerogels (Zn-ALG), blank alginate aerogels (ALG) and pure Zn(II)-AHBD catalyst $(\mathrm{Zn})$, respectively.

\subsection{Aerogels Images}

The images of the impregnated alginate and silica aerogels are presented in the Figures 8 and 9, respectively. Figure 8 shows images of several alginate aerogels, namely, blank aerogel sample (a), Zn(II)-AHBD-impregnated aerogel (b), Zn(II)-AHBD+[Aliquat][Cl]impregnated aerogel (c) and aerogel impregnated only with [Aliquat][Cl] (d). Zn(II)-AHBDimpregnated aerogels (Figure $8 \mathrm{~b}, \mathrm{c}$ ) present a brown colour, indicating the presence of the $\mathrm{Zn}(\mathrm{II})-\mathrm{AHBD}$ catalyst in the matrix. The same characteristics were observed for the exterior and interior of the impregnated aerogels, indicating a homogeneous loading of the whole aerogel monolith. [Aliquat][Cl]-impregnated samples (Figure $8 \mathrm{~d}$ ) presented a yellowish appearance due to the presence of the ionic liquid, which contrasted with the blank samples (Figure 8a). Again, a homogeneous loading of the whole aerogel monolith was observed.

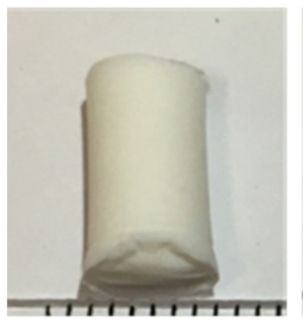

(a)

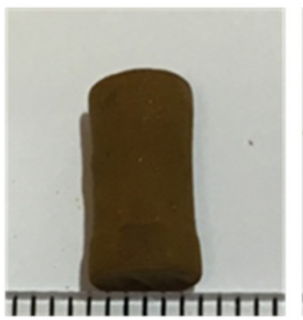

(b)

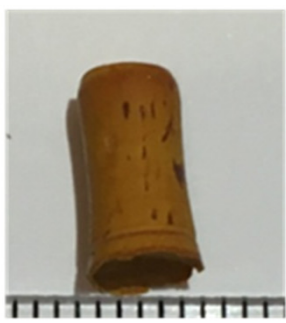

(c)

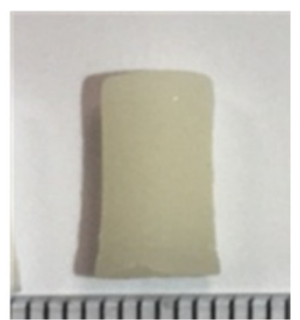

(d)

Figure 8. Images of alginate aerogels: alginate aerogels, (a) blank, (b) Zn(II)-AHBD-impregnated, (c) $\mathrm{Zn}(\mathrm{II})-\mathrm{AHBD}+[$ Aliquat $][\mathrm{Cl}]$-impregnated, (d) [Aliquat][Cl]-impregnated.

In Figure 9a,b are presented images of the silica aerogels SIL1 and SIL2. The first sample is a blank aerogel, followed by a $\mathrm{Zn}$ (II)-AHBD impregnated aerogel and in the case of image 11b) also Zn(II)-AHBD+[Aliquat][Cl] impregnated silica aerogel. 


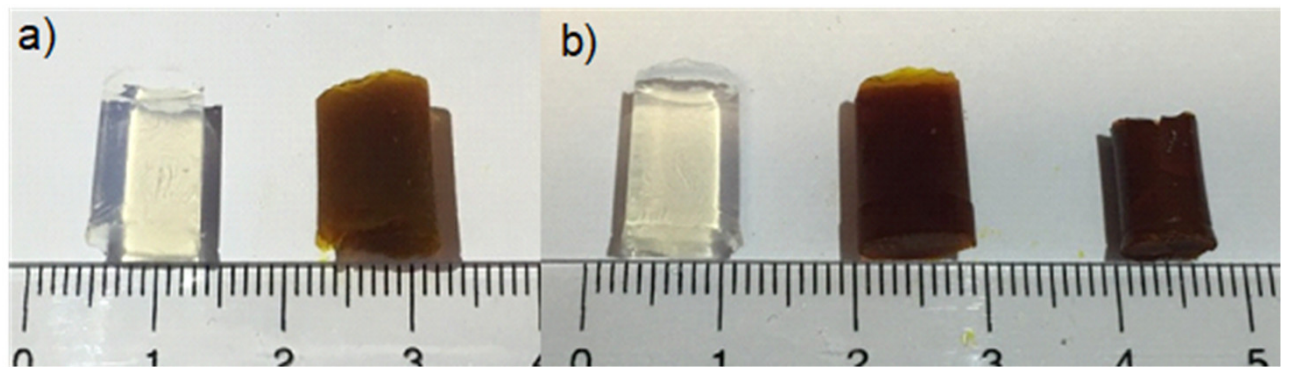

Figure 9. Images of Silica aerogels: (a) SIL1: Blank and Zn(II)-AHBD impregnated, respectively; (b) SIL2: Blank, Zn(II)-AHBD impregnated and Zn(II)-AHBD + [Aliquat][Cl] impregnated, respectively.

\subsection{Scanning Electron Microscopy}

The SEM micrographs of silica and alginate aerogels are presented in the Figures 10 and 11, respectively. Two different magnifications were performed, 5.000 and 30.000 , to detect different details of the surface morphology.

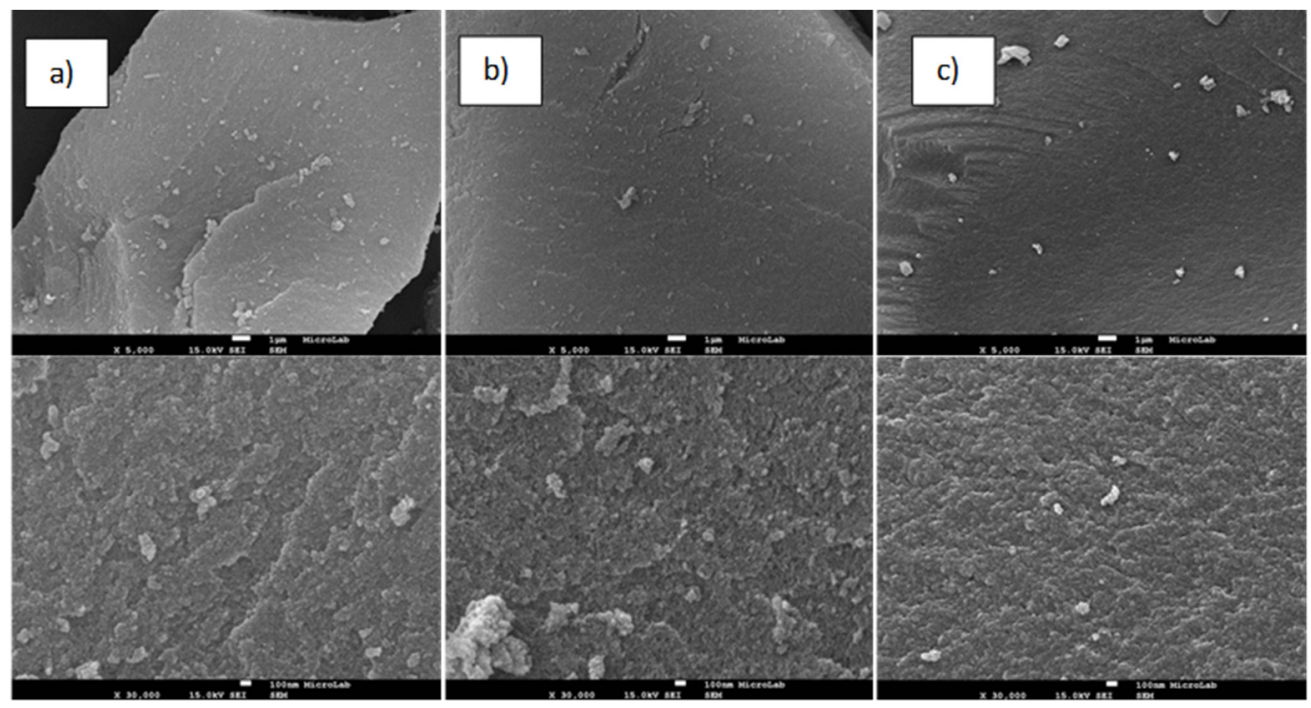

Figure 10. SEM images of silica aerogels (SIL2): (a) blank sample, (b) Zn(II)-AHBD impregnation and (c) $\mathrm{Zn}(\mathrm{II})-\mathrm{AHBD}+[$ Aliquat] [Cl] impregnation. The first line corresponds to a 5.000 magnification and the second line 30.000 magnification.

No changes on the surface morphology of silica aerogels after the impregnation were observed (Figure 10). Therefore, the discussions on the effect of impregnation on surface morphology will be focused on the alginate aerogels (Figure 11). In Figure 11a, we observe that the blank alginate aerogel presents a high porous open structure, typical of the surface morphology of alginate aerogels [48].

On the other hand, the $\mathrm{Zn}(\mathrm{II})-\mathrm{AHBD}$-impregnated alginate aerogels (Figure 11b exhibit linkages of granular material, indicating the deposition of $\mathrm{Zn}$ (II)-AHBD on the surface structure of alginate aerogel. When alginate aerogels were impregnated with $\mathrm{Zn}$ (II)$\mathrm{AHBD}$ and [Aliquat][Cl] (Figure 11c), the alginate matrix presented no pores and increased thickness. This suggests a high absorption of [Aliquat][Cl] and $\mathrm{Zn}(\mathrm{II})$-AHBD from the ethanol medium and as consequence the change of the textural structure of the aerogels. The same result was obtained when only [Aliquat][Cl] was impregnated (Figure 11d). The SEM images presented are related to the sample impregnated during $48 \mathrm{~h}$ with $20 \mathrm{~mL}$ [Aliquat][Cl] and $10 \mathrm{~mL}$ of ethanol, but similar results were obtained for the others. 


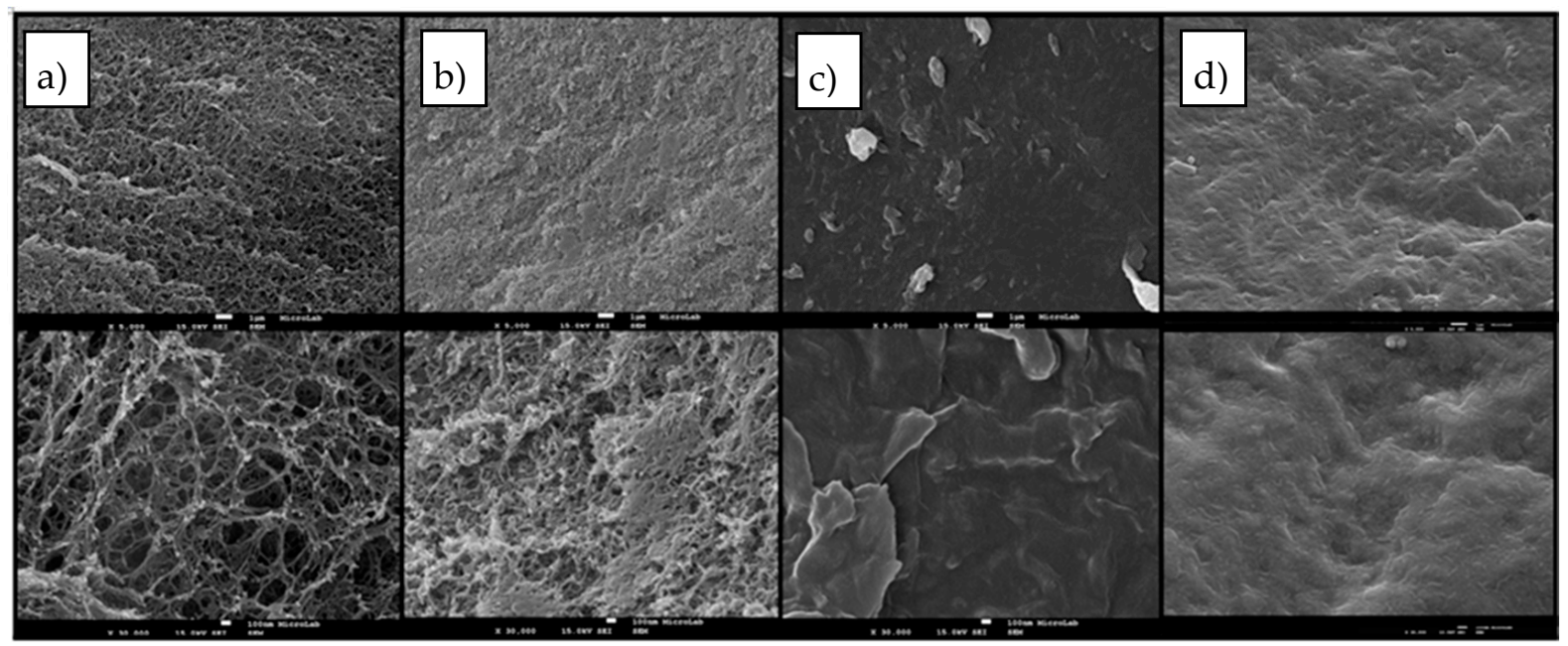

Figure 11. SEM images of alginate aerogels: (a) blank, (b) Zn(II)-AHBD impregnation, (c) Zn(II)-AHBD + [Aliquat][Cl] impregnation and (d) [Aliquat][Cl] impregnation. The first line corresponds to a 5.000 magnification and the second line to a 30.000 magnification.

\subsection{Atomic Absorption Studies}

The metal loading was determined by atomic absorption. All the samples were analysed (except the ones impregnated only with [Aliquat][Cl]). However, the only sample for which $\mathrm{Zn}(\mathrm{II})-\mathrm{AHBD}$ was detected was the alginate aerogel impregnated with $\mathrm{Zn}$ (II)AHBD (Zn-ALG). For all the other samples, it was not possible to quantify the Zn(II)-AHBD loading since it was below the detection limit. The concentration obtained for Zn-ALG was only $1.99 \%(w / w)$. For Zn-IL-ALG, the presence of Aliquat $\mathrm{Cl}$ has significantly reduced the complex solubility in the solution, decreasing the zinc concentration on the materials to bellow the detection limit (which is $8 \mathrm{ppb}$ ).

For silica aerogels, textural properties seem to evidence a significant impregnation level, which was not detected by the atomic absorption studies, namely for Zn-SIL2. In this case, the complex should have suffered a process of decomposition in contact with the silica material. Therefore, both textural results and the brown color observed are not due to the presence of zinc, but due to the presence of the ligand AHBD.

\subsection{Reactions Using Impregnated Aerogels as Catalysts}

Impregnated alginate and silica aerogels were evaluated as catalytic systems for the coupling reaction between $\mathrm{CO}_{2}$ and limonene oxide (Figure 12). The results are summarized in Table 3.

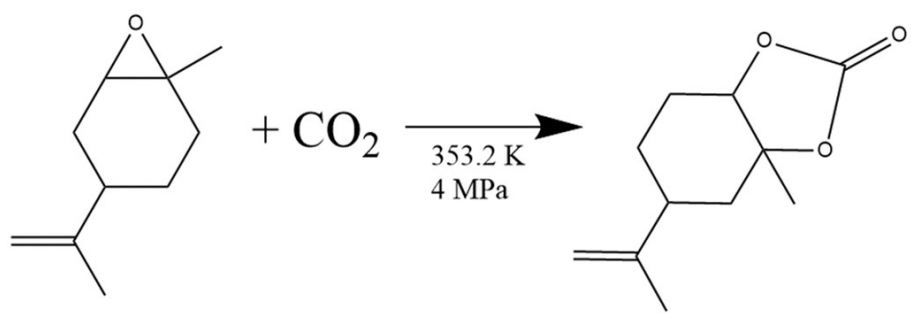

Figure 12. Synthesis of cyclic carbonates from $\mathrm{CO}_{2}$ and epoxides. 
Table 3. Limonene carbonate formation after $48 \mathrm{~h}$ at $353.2 \mathrm{~K}$ and $4 \mathrm{MPa}$, using $1 \mathrm{~mL}$ of limonene oxide and different impregnated aerogels as catalyst support.

\begin{tabular}{cccc}
\hline Matrix & Material Reference & Impregnation & $\begin{array}{c}\text { Carbonate } \\
\text { Formation }\end{array}$ \\
\hline \multirow{3}{*}{ Silica } & Zn-SIL1 & Zn(II)-AHBD & $0 \%$ \\
& Zn-SIL2 & Zn(II)-AHBD & $0 \%$ \\
& Zn-IL-SIL2 & Zn(II)-AHBD + IL & $<5 \%$ \\
\hline \multirow{2}{*}{ Alginate } & Zn-ALG & Zn(II)-AHBD & $0 \%$ \\
& Zn-IL-ALG & Zn(II)-AHBD + IL & $35 \%$ \\
& IL-ALG & IL & $32 \%$ \\
\hline
\end{tabular}

${ }^{a}$ Carbonate formation determined by integration of the 1H-NMR spectrum of the crude reaction mixture.

Based on our previous studies, all the reactions were performed for $48 \mathrm{~h}$, at $353.2 \mathrm{~K}$ and $4 \mathrm{MPa}$, using $1 \mathrm{~mL}$ of limonene oxide $[39,53,54]$. It should be noted that the aerogel was never used in direct contact with the liquid phase. All reactions were carried out maintaining the aerogel supported in a metallic grid at the top of the reactor in contact with the $\mathrm{CO}_{2}$ gaseous phase as described in the methodology section. All investigated catalytic systems presented more than $95 \%$ selectivity towards limonene carbonate production.

As shown by the results presented in Table 3, all tested silica aerogels showed practically no activity towards the coupling reaction between $\mathrm{CO}_{2}$ and limonene oxide.

For the materials with references Zn-SIL1 and Zn-SIL2, which are two different silica aerogels impregnated only with the zinc complex, this result can be explained by the absence of the ionic liquid [Aliquat][Cl].

In fact, results show that even when supported in a silica material, the presence of the chloride anion still plays a crucial effect on the reaction mechanism. Curiously, also for the material with reference Zn-IL-SIL2, which was a silica aerogel impregnated with both zinc complex and [Aliquat][Cl], only a small amount of carbonate formation was observed under the experimental conditions studied.

Alginate aerogels were used as catalyst support for the cycloaddition between $\mathrm{CO}_{2}$ and epoxides. A surprisingly high carbonate formation of $35 \%$ and $32 \%$ was obtained for materials with reference Zn-IL-ALG and IL-ALG, respectively. On the other hand, as for the case of silica aerogels, materials impregnated only with zinc complex (Zn-ALG) gave no carbonate formation. Furthermore, both aerogels Zn-IL-ALG (impregnated with zinc complex and [Aliquat][Cl]) and IL-ALG (impregnated only with [Aliquat][Cl]) presented nearly the same activity, although being slightly higher for the former, which is in line with the conclusion that the zinc complex was impregnated in very low amounts. ILALG materials impregnated only with [Aliquat][Cl] were able to efficiently catalyse the reaction due to high [Aliquat][Cl] loadings. The results obtained are in accordance with the general proposed reaction mechanism in which the nucleophile is responsible for the attack to the epoxide ring, which is the rate-determining step [54]. Although IL-ALG materials presented satisfactory catalytic activities, their reutilization was not tested due to the leaching of the ionic liquid during the reactor depressurization at the end of each experiment. This happens mainly due to the high polarity of the substrate used, limonene oxide. Operating in continuous mode under high $\mathrm{CO}_{2}$ /epoxide ratios will in the future allow to overcome this limitation.

\section{Experimental Section}

\subsection{Materials and Equipment}

All chemicals and solvents were purchased from commercial suppliers and used as received without further purification. Carbon dioxide ( $>99.95 \mathrm{~mol} \%$ purity) was supplied by Air Liquide(Paris, France) and Carburos Metálicos. Limonene oxide ( $97 \mathrm{~mol} \%$ purity), [Aliquat][Cl] (Trioctylmethylammonium chloride), chloroform, deuterated chloroform, alginic acid sodium salt from brown algae (low viscosity, $4-15 \mathrm{cP})$, calcium carbonate $\left(\mathrm{CaCO}_{3}\right)$ and glucono- $\delta$-lactone (GDL), tetramethoxysilane (TMOS), methanol, ammonium hydroxide 
$\left(\mathrm{NH}_{4} \mathrm{OH}\right)$ were purchased from Sigma-Aldrich. A zinc(II) complex of an arylhydrazone of a $\beta$-diketone ( $\mathrm{Zn}(\mathrm{II})$-AHBD) was prepared as reported in previous works [46,47].

The following equipment was used for materials characterization, FTIR Thermo Nicolet 6700 (Thermofisher Scientific, Waltham, MA, USA), X-ray diffraction Discover D8 (Bruker, Birrica, MA, USA), JEM-2200FS HRP Field Emission Electron Microscope (JEOL, Shishima City, Tokyo, Japan), SEM-7001F FE-SEM, Analytical (JEOL).

\subsection{Preparation of Alcogels}

3.2.1. Silica Alcogels Synthesis

The silica alcogels were produced by sol-gel process with two different approaches (SIL1 and SIL2). In the first approach, SIL1, TMOS and methanol were mixed and then a solution of ammonium hydroxide-water was added drop by drop under stirring. A molar ratio of 1 mol TMOS: 3 mol MeOH: $4 \mathrm{~mol} \mathrm{H}_{2} \mathrm{O}: 5 \times 10^{-3} \mathrm{~mol} \mathrm{NH}_{4} \mathrm{OH}$ was used [55]. In the second approach, SIL2, TMOS was mixed with water, methanol, and hydrochloric acid and a solution of ammonium hydroxide-water was added drop by drop under stirring conditions. A molar ratio 1 mol TMOS: $2.4 \mathrm{~mol} \mathrm{MeOH}: 1.3 \mathrm{~mol} \mathrm{H}_{2} \mathrm{O}: 1 \times 10^{-5} \mathrm{~mol} \mathrm{HCl}$ : $7.7 \times 10^{-4} \mathrm{~mol} \mathrm{NH}_{4} \mathrm{OH}$ was used [56]. For both approaches, the final mixture was stirred at room temperature for $30 \mathrm{~min}$. The resulting mixture was poured into moulds covered with parafilm for gelation. After fifteen min, the gels formed were immersed into methanol for aging process, which lasted at least 7 days. The solvent was changed at least twice during aging to completely remove excess water and traces of reactants from the alcogels.

\subsubsection{Alginate Alcogels Synthesis}

Alginate hydrogels were prepared via internal gelation based on lowering the $\mathrm{pH}$ as described elsewhere $[57,58]$. In this work, sodium alginate was dissolved in distilled water under stirring conditions of $400 \mathrm{rpm}$ for $2 \mathrm{~h}$. Then, calcium carbonate was added into the solution and stirred for $1 \mathrm{~h}$. After $1 \mathrm{~h}$ the addition of GDL was performed, reducing the $\mathrm{pH}$ of the solution and allowing it to turn into a gel. The final concentrations of sodium alginate, $\mathrm{CaCO}_{3}$ and GDL are $3.2 \%(w / w), 1.6 \%(w / w)$ and $1.4 \%(w / w)$, respectively. The resulting mixture was placed into moulds, covered with parafilm and stored in refrigerator $\left(4{ }^{\circ} \mathrm{C}\right)$ for $18 \mathrm{~h}$ to become solidified. Then, the alginate hydrogels were immersed in an aqueous solution with $30 \%(v / v)$ of ethanol and a multistep solvent exchange was followed every $24 \mathrm{~h}$ using ethanol-water solutions with increasing ethanol volumetric ratios of $50 \%$, $70 \%$, and $90 \%$. Finally, pure ethanol was exchanged twice in order to totally replace the water content of the hydrogel by ethanol before the supercritical $\mathrm{CO}_{2}$ drying.

\subsection{Aerogels Impregnation}

After the solvent exchange period, a wet impregnation (WI) method was used in order to impregnate the $\mathrm{Zn}$ (II)-AHBD complex into the aerogels matrix [48]. First, the $\mathrm{Zn}$ (II)-AHBD complex was dissolved in an organic solvent to produce a saturated solution $(15,000 \mathrm{ppm})$, ethanol was used in the case of alginate aerogels and methanol for silica aerogels. The solution $(30 \mathrm{~mL})$ was placed into contact with the final alcogels to allow the $\mathrm{Zn}$ (II)-AHBD complex diffusion into the pores of alcogels until equilibration was reached. About 12 alcogel monoliths were added and maintained into a $30 \mathrm{~mL}$ solution for $48 \mathrm{~h}$. In the case of the impregnation of both $\mathrm{Zn}(\mathrm{II})-\mathrm{AHBD}$ and [Aliquat][Cl], the procedure was very similar, being the only difference the use of $0.45 \mathrm{~g}$ of $\mathrm{Zn}$ (II)-AHBD in $20 \mathrm{~mL}$ of solvent, plus $10 \mathrm{~mL}$ of [Aliquat][Cl]. Also, 12 alcogel monoliths (aged for 7 days) were added and maintained into the solution for $48 \mathrm{~h}$. In the case of the impregnation only with [Aliquat][Cl] only, the alginate aerogels were impregnated, and the procedure consisted in using $20 \mathrm{~mL}$ of solvent and $10 \mathrm{~mL}$ of [Aliquat][Cl]. The 12 alcogel monoliths (aged for 7 days) were added and maintained into a $30 \mathrm{~mL}$ solution for $48 \mathrm{~h}$. Successively, the solvent was extracted by supercritical $\mathrm{CO}_{2}$ drying, leading to the precipitation of the compounds on the surface and pores of aerogels due to their insolubility in $\mathrm{CO}_{2}$. 


\subsection{Supercritical Drying of Alcogels}

The supercritical $\mathrm{CO}_{2}$ drying of the alcogels (silica and alginate) was performed at $14 \pm 0.5 \mathrm{MPa}$ and $45^{\circ} \mathrm{C}$, employing the procedure and equipment described in a previous work (Figure 13) [59].

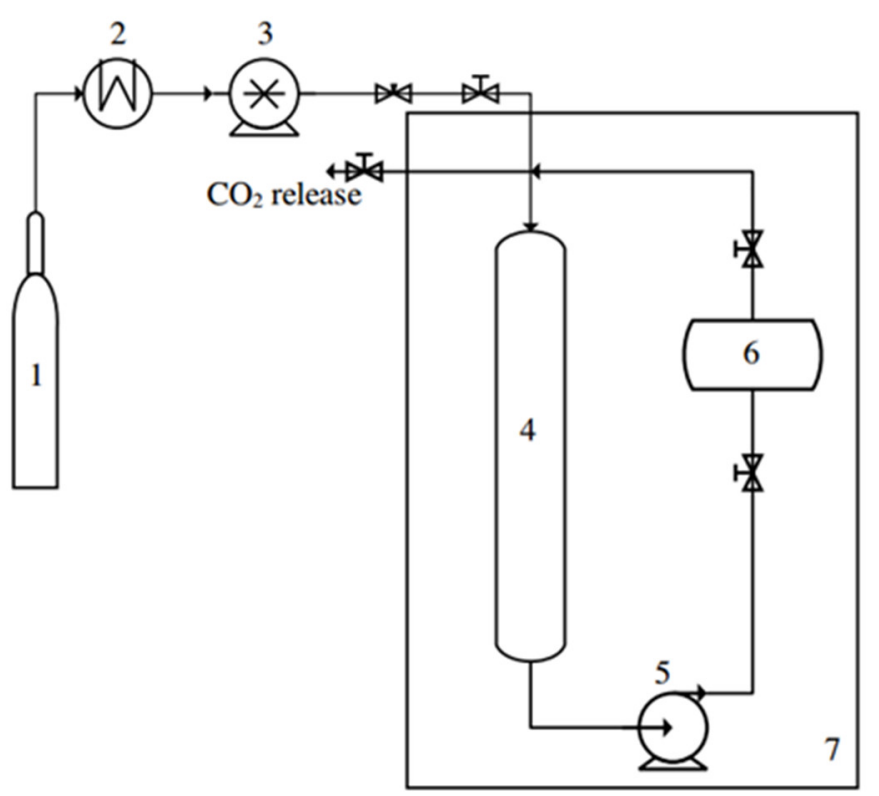

Figure 13. Supercritical $\mathrm{CO}_{2}$ drying setup; (1) $\mathrm{CO}_{2}$ tank, (2) cooler, (3) pump, (4) $\mathrm{CO}_{2}$ buffer, (5) pump, (6) view cell chamber and (7) oven.

About 12 alcogels were placed in the drying reactor and then filled with solvent (ethanol in the case of alginate and methanol in the case of silica) to prevent damage of alcogel structure during the pressurization of the system. The system was slowly pressurized to the desired pressure at a rate of $0.4 \mathrm{MPa} / \mathrm{min}$. After the operating conditions of drying were reached, the solvent in the reactor was slowly removed by opening the lower valve. This strategy allows a continuous circulation of $\mathrm{CO}_{2}$ to extract the solvent from the alcogels. The drying process was conducted in three cycles of $60 \mathrm{~min}$ minimum each. At the end of the three cycles, the system was slowly depressurized at a rate of $0.2 \mathrm{MPa} / \mathrm{min}$ in order to avoid shrinkage or damage of aerogels.

\section{5. $\mathrm{CO}_{2}$ and Epoxides Coupling Reactions}

The reactions were performed in a high-pressure reactor presented in Figure 14 and described in detail elsewhere [54]. This set-up is built around a stainless-steel cylindrical cell with two sapphire windows and an internal volume of approximately $11 \mathrm{~cm}^{3}$. Inside the reactor a metallic net is used to support the aerogel in order to avoid any contact between the aerogel and the liquid phase-see details in Figure 14. A magnetic stirring bar was introduced inside the cell in order to homogenise the solution.

First, the reactor was filled with limonene oxide, catalyst (SILP or bulk) and $1 \mathrm{MPa}$ of $\mathrm{CO}_{2}$ pressure. Then, the reactor was immersed in a thermostated silicone bath heated by means of a controller that maintained the temperature within $\pm 0.1^{\circ} \mathrm{C}$. By operating a $\mathrm{CO}_{2}$-compressor, the desired pressure was attained into the cell. The pressure in the cell was measured with a pressure transducer 204 Setra ( $\pm 0.073 \%$ full scale accuracy). At the end of the reaction, the high-pressure cell was cooled and then slowly depressurized to atmospheric pressure. Afterward, the cell was opened, and the content was collected. The crude reaction mixture was analysed by NMR using deuterated chloroform as a solvent. NMR spectra were recorded on Bruker $500 \mathrm{MHz}$ type (400 MHz) (Birrica, MA, USA). Peak frequencies were compared against solvent, chloroform-d at 7.26 ppm. All liquid solutions 
were prepared gravimetrically using an analytical balance (Sartorius model R180D) with the precision of $\pm 0.0001 \mathrm{~g}$.

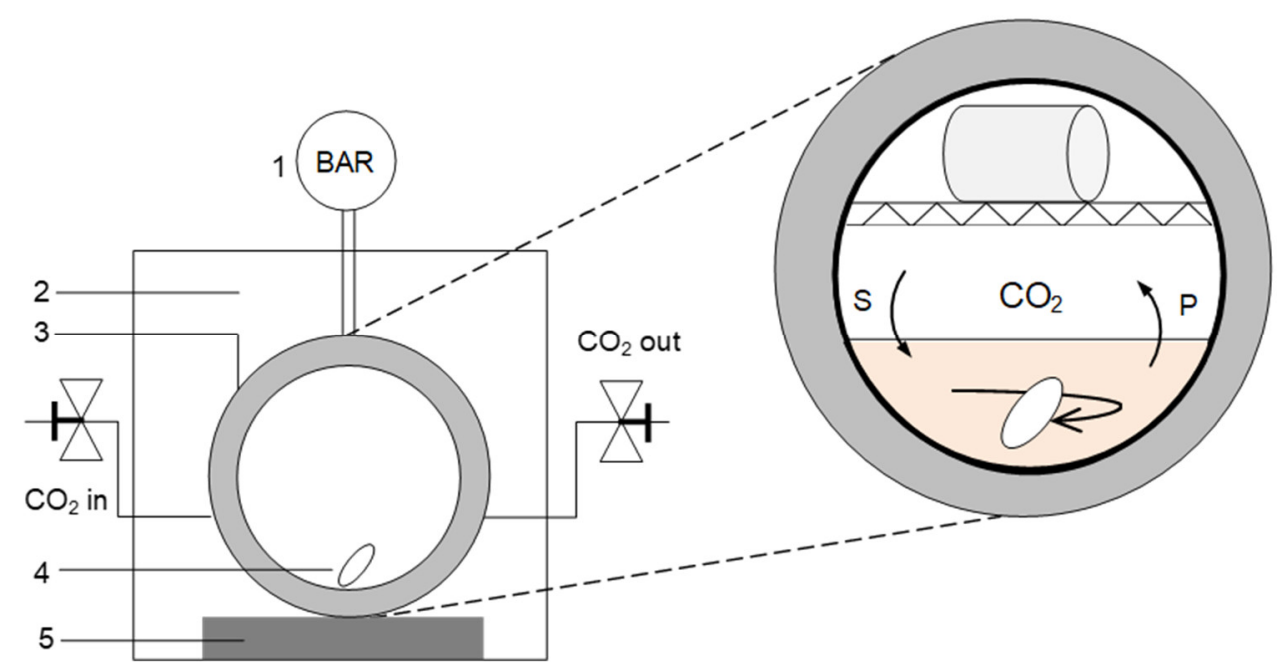

Figure 14. High pressure apparatus: 1-Pressure transducer, 2-Thermostated water bath, 3-Stainless steel cylindrical cell, 4-Magnetic stirring bar, 5-Stir Plate.

The carbonate formation was determined by integration of the $1 \mathrm{H}-\mathrm{NMR}$ spectrum of the crude reaction mixture. The calculations were made using the signals from the epoxy groups of limonene oxide $(\delta=2.9-3.1 \mathrm{ppm})$ and from the cyclic carbonate groups $(\delta=4.3-4.5 \mathrm{ppm})$ [60]. Errors in the carbonate formation measurements were estimated by comparing the results of at least 3 integrations of each spectrum. The error in the final results was lower than $10 \%$.

\subsection{Aerogels Characterization}

The aerogel structure was studied by Fourier transform infrared spectroscopy. The spectra were acquired between 4000 and $400 \mathrm{~cm}^{-1}$ with a $4 \mathrm{~cm}^{-1}$ step using an attenuated total reflectance (ATR) sampling accessory (Smart iTR) equipped with a single-bounce diamond crystal on a Thermo Nicolet 6700 Spectrometer.

Textural characteristics of aerogels, mainly specific surface area, mean pore diameter and pore size distribution, were determined by $\mathrm{N} 2$ adsorption-desorption analysis at low temperature (NOVA 3000e). The specific pore volume is determined by the single point adsorption method. The shown average pore diameter is based on the desorption isotherm of the Barrett-Joyner-Halenda (BJH) method. Prior to the determination, the alginate and silica aerogels were degassed at 70 and $200{ }^{\circ} \mathrm{C}$, respectively, under vacuum $(<1 \mathrm{mPa})$ for $20 \mathrm{~h}$. The specific area was calculated by the method of Brunauer, Emmett, Teller (BET) and the pore size distribution was calculated from the desorption isotherm.

The crystallinity of the impregnated Zn(II)-AHBD aerogel particles was analyzed by Xray diffraction (Discover D8-Bruker). A JEOL field emission microscope, model JEM-FS2200 HRP, operating at $200 \mathrm{kV}$ was used for EDX (Energy-Dispersive X-ray spectroscopy).

Particle morphology of the aerogels were analysed by Field Emission Scanning Microscopy (FE-SEM JEOL 7001F). Before analysis the aerogel particles were covered with approximately $300 \mathrm{~A}^{\circ}$ of gold by a sputter-coater in argon atmosphere (Polaron).

The metal loading of the aerogels was determined by atomic absorption (AA) using a VARIAN SPECTRA 220FS analyser. Digestion of the samples was performed with $\mathrm{HCl}$, $\mathrm{H} 2 \mathrm{O} 2$ and $\mathrm{HF}$ using microwave at $250{ }^{\circ} \mathrm{C}$.

\section{Conclusions}

Alginate and silica aerogels were prepared and explored as supports for the ionic liquid [Aliquat][Cl] and applied as catalysts on the cycloaddition reaction between $\mathrm{CO}_{2}$ and 
limonene oxide. Surprisingly, alginate impregnated aerogel materials presented a much higher efficiency as catalysts in comparison with silica aerogels. Physical characterizations showed differences on the impregnation efficiency of [Aliquat][Cl] into alginate and silica aerogels, very likely due to differences in the pore size of the aerogels. This method takes advantage of both homogeneous (high rates and good selectivity) and heterogeneous catalysis (easy separation) together with the utilization of a bio-based support with high catalyst loadings.

Author Contributions: The manuscript was written through contributions of all authors. All authors have read and agreed to the published version of the manuscript.

Funding: This research received no external funding.

Acknowledgments: This work was supported by Ministerio de Ciencia y Universidades (project RTI2018-097456-B-I00) and Fundação para a Ciência e Tecnologia FCT/MCTES (project PTDC/EQUEPQ/31926/2017), UIDB/50006/2020 of the Associate Laboratory for Green Chemistry-LAQV and UIDB/00100/2020 of Centro de Química Estrutural. This work was also supported by a Short Term Scientific Mission of the CMST COST Action CM1206. A.B. Paninho is thankful to FCT for the doctoral fellowship PD/BD/52497/2014 and pos-doctoral fellowship PTDC/EQU-EPQ/31926/2017. The authors also thanks to the project "SunStorage-Harvesting and storage of solar energy", with reference POCI-01-0145-FEDER-016387, funded by European Regional Development Fund (ERDF), through COMPETE 2020-Operational Program. The NMR spectrometers at FCT NOVA are part of Rede Nacional de RMN (PTNMR), supported by FCT/MCTES through ROTEIRO/0031/2013PINFRA/22161/2016 and co-financed by FEDER through COMPETE 2020, POCI, and PORL and FCT/MCTES through PIDDAC.

Conflicts of Interest: The authors declare no conflict of interest.

\section{References}

1. Machado, A.S.R.; Nunes, A.V.M.; Nunes da Ponte, M. Carbon dioxide utilization-Electrochemical reduction to fuels and synthesis of polycarbonates. J. Supercrit. Fluids 2018, 134, 150-156. [CrossRef]

2. Kamphuis, A.J.; Picchioni, F.; Pescarmona, P.P. $\mathrm{CO}_{2}$-fixation into cyclic and polymeric carbonates: Principles and applications. Green Chem. 2019, 21, 406-448. [CrossRef]

3. Schäffner, B.; Schäffner, F.; Verevkin, S.P.; Börner, A. Organic carbonates as solvents in synthesis and catalysis. Chem. Rev. 2010, 110, 4554-4581. [CrossRef] [PubMed]

4. North, M.; Pasquale, R.; Young, C. Synthesis of cyclic carbonates from epoxides and $\mathrm{CO}_{2}$. Green Chem. 2010, 12, 1514-1539. [CrossRef]

5. Martin, C.; Fiorani, G.; Kleij, A.W. Recent advances in the catalytic preparation of cyclic organic carbonates. ACS Catal. 2015, 5, 1353-1370. [CrossRef]

6. Shaikh, R.R.; Pornpraprom, S.; D'Elia, V. Catalytic Strategies for the cycloaddition of pure, diluted, and waste $\mathrm{CO}_{2}$ to epoxides under ambient conditions. ACS Catal. 2018, 8, 419-450. [CrossRef]

7. Büttner, H.; Longwitz, L.; Steinbauer, J.; Wulf, C.; Werner, T. Recent developments in the synthesis of cyclic carbonates from epoxides and $\mathrm{CO}_{2}$. Top. Curr. Chem. 2017, 375, 50-106. [CrossRef]

8. Cokoja, M.; Wilhelm, M.E.; Anthofer, M.H.; Herrmann, W.A.; Kühn, F.E. Synthesis of cyclic carbonates from epoxides and carbon dioxide by using organocatalysts. ChemSusChem 2015, 8, 2436-2454. [CrossRef]

9. Bobbink, F.D.; Dyson, P.J. Synthesis of carbonates and related compounds incorporating $\mathrm{CO}_{2}$ using ionic liquid-type catalysts: State-of-the-art and beyond. J. Catal. 2016, 343, 52-61. [CrossRef]

10. Alves, M.; Grignard, B.; Mereau, R.; Jerome, C.; Tassaing, T.; Detrembleur, C. Organocatalyzed coupling of carbon dioxide with epoxides for the synthesis of cyclic carbonates: Catalyst design and mechanistic studies. Catal. Sci. Technol. 2017, 7, 2651-2684. [CrossRef]

11. Chen, Y.; $\mathrm{Mu}, \mathrm{T}$. Conversion of $\mathrm{CO}_{2}$ to value-added products mediated by ionic liquids. Green Chem. 2019, 21, 2544-2574. [CrossRef]

12. Paninho, A.B.; Ventura, A.; Branco, L.C.; Pombeiro, A.J.L.; Guedes da Silva, M.F.C.; Nunes da Ponte, M.; Mahmudov, K.T.; Nunes, A.V.M. $\mathrm{CO}_{2}+$ ionic liquid biphasic system for reaction/product separation in the synthesis of cyclic carbonates. J. Supercrit. Fluids 2018, 132, 71-75. [CrossRef]

13. Serbanovic, A.; Branco, L.C.; Nunes da Ponte, M.; Afonso, C.A.M. Osmium catalyzed asymmetric dihydroxylation of methyl trans-cinnamate in ionic liquids, followed by supercritical $\mathrm{CO}_{2}$ product recovery. J. Organomet. Chem. 2005, 690, 3600-3608. [CrossRef] 
14. Franciò, G.; Hintermair, U.; Leitner, W. Unlocking the potential of supported liquid phase catalysts with supercritical fluids: Low temperature continuous flow catalysis with integrated product separation. Philos. Trans. R. Soc. A 2015, 373, 1-26. [CrossRef] [PubMed]

15. Calabrese, C.; Giacalone, F.; Aprile, C. Hybrid catalysts for $\mathrm{CO}_{2}$ conversion into cyclic carbonates. Catalysts 2019, 9, 325. [CrossRef]

16. Mehnert, C.P.; Cook, R.A.; Dispenziere, N.C.; Afeworki, M. Supported ionic liquid catalysis-A new concept for homogeneous hydroformylation catalysis. J. Am. Chem. Soc. 2002, 124, 12932-12933. [CrossRef] [PubMed]

17. Riisager, A.; Fehrmann, R.; Haumann, M.; Wasserscheid, P. Supported ionic liquid phase (SILP) catalysis: An innovative concept for homogeneous catalysis in continuous fixed-bed reactors. Eur. J. Inorg. Chem. 2006, 4, 695-706. [CrossRef]

18. Romanovsky, B.V.; Tarkhanova, I.G. Supported ionic liquids in catalysis. Russ. Chem. Rev. 2017, 86, 444-458. [CrossRef]

19. Kaur, P.; Chopra, H.K. Recent advances in applications of supported ionic liquids. Curr. Org. Chem. 2019, 23, 2881-2915. [CrossRef]

20. Wang, Y.; Guo, L.; Yin, L. Progress in the heterogeneous catalytic cyclization of $\mathrm{CO}_{2}$ with epoxides using immobilized ionic liquids. Catal. Lett. 2019, 149, 985-997. [CrossRef]

21. Lemus, J.; Palomar, J.; Gilarranz, M.A. Characterization of supported ionic liquid phase (SILP) materials prepared from different supports. J. Intern. Adsorp. Soc. 2011, 17, 561-571. [CrossRef]

22. Zhu, J.; Wang, S.; Gu, Y.; Xue, B.; Li, Y. A new and efficient method of graphene oxide immobilized with ionic liquids: Promoted catalytic activity for $\mathrm{CO}_{2}$ cycloaddition. Mater. Chem. Phys. 2018, 208, 68-76. [CrossRef]

23. Guo, L.; Deng, L.; Jin, X.; Wang, Y.; Wang, H. Catalytic conversion of $\mathrm{CO}_{2}$ into propylene carbonate in a continuous fixed bed reactor by immobilized ionic liquids. RSC Adv. 2018, 8, 26554-26562. [CrossRef]

24. Hu, Y.L.; Zhang, R.L.; Fang, D. Quaternary phosphonium cationic ionic liquid/porous metal-organic framework as an efficient catalytic system for cycloaddition of carbon dioxide into cyclic carbonates. Environ. Chem. Lett. 2019, 17, 501-508. [CrossRef]

25. Wang, T.; Wang, W.; Lyu, Y.; Chen, X.; Li, C.; Zhang, Y.; Song, X.; Ding, Y. Highly recyclable polymer supported ionic liquids as efficient heterogeneous catalysts for batch and flow conversion of $\mathrm{CO}_{2}$ to cyclic carbonates. RSC Adv. 2017, 7, $2836-2841$. [CrossRef]

26. Sang, Y.; Huang, J. Benzimidazole-based hyper-cross-linked poly(ionic liquid)s for efficient $\mathrm{CO}_{2}$ capture and conversion. Chem. Eng. J. 2020, 1385, 123973-123982. [CrossRef]

27. Li, J.; Jia, D.; Guo, Z.; Liu, Y.; Lyu, Y.; Zhou, Y.; Wang, J. Imidazolinium based porous hypercrosslinked ionic polymers for efficient $\mathrm{CO}_{2}$ capture and fixation with epoxides. Green Chem. 2017, 19, 2675-2686. [CrossRef]

28. Martínez-Ferraté, O.; Chacón, G.; Bernardi, F.; Grehl, T.; Brüner, F.; Dupont, J. Cycloaddition of carbon dioxide to epoxides catalysed by supported ionic liquids. Catal. Sci. Technol. 2018, 8, 3081-3089. [CrossRef]

29. Martinez, A.S.; Hauzenberger, C.; Sahoo, A.R.; Csendes, Z.; Hoffmann, H.; Bica, K. Continuous conversion of carbon dioxide to propylene carbonate with supported ionic liquids. ACS Sustain. Chem. Eng. 2018, 6, 13131-13139.

30. Kolle, J.M.; Sayari, A. Substrate dependence on the fixation of $\mathrm{CO}_{2}$ to cyclic carbonates over reusable porous hybrid solids. J. CO2 Util. 2018, 26, 564-574. [CrossRef]

31. Ramalingam, R.J.; Appaturi, J.N. Synthesis, characterization and catalytic activity of ionic liquid mimic halides modified MCM-41 for solvent free synthesis of phenyl glycidyl carbonate. Mater. Chem. Phys. 2019, 233, 79-88. [CrossRef]

32. Hu, Y.L.; Wang, H.B.; Chen, Z.W.; Li, X.G. Titanium incorporated mesoporous silica immobilized functional ionic liquid as an efficient reusable catalyst for cycloaddition of carbon dioxide to epoxides. Chem. Select 2018, 3, 5087-5091. [CrossRef]

33. Takahashi, T.; Watahiki, T.; Kitazume, S.; Yasuda, H.; Sakakura, T. Synergistic hybrid catalyst for cyclic carbonate synthesis: Remarkable acceleration caused by immobilization of homogeneous catalyst on silica. Chem. Commun. 2006, 1, 1664-1666. [CrossRef]

34. Hajipour, A.R.; Heidari, Y.; Kozehgary, G. Silica grafted ammonium salts based on DABCO as heterogeneous catalyst for cyclic carbonate synthesis from carbon dioxide and epoxides. RSC Adv. 2015, 5, 22373-22379. [CrossRef]

35. Sakai, T.; Tsutsumi, Y.; Ema, T. Highly active and robust organic-inorganic hybrid catalyst for the synthesis of cyclic carbonates from carbon dioxide and epoxides. Green Chem. 2008, 10, 337-341. [CrossRef]

36. Roshan, K.R.; Mathai, G.; Kim, J.; Tharun, J.; Parka, G.A.; Park, D.W. A biopolymer mediated efficient synthesis of cyclic carbonates from epoxides and carbon dioxide. Green Chem. 2012, 14, 2933-2940. [CrossRef]

37. Sun, J.; Wang, J.; Cheng, W.; Zhang, J.; Li, X.; Zhang, S.; Sheb, Y. Chitosan functionalized ionic liquid as a recyclable biopolymersupported catalyst for cycloaddition of $\mathrm{CO}_{2}$. Green Chem. 2012, 14, 654-660. [CrossRef]

38. Taheri, M.; Ghiaci, M.; Shchukarev, A. Cross-linked chitosan with a dicationic ionic liquid as a recyclable biopolymer-supported catalyst for cycloaddition of carbon dioxide with epoxides into cyclic carbonates. New J. Chem. 2018, 42, 587-597. [CrossRef]

39. Paninho, A.B. Sustainable intensification strategies for the production of cyclic carbonates from $\mathrm{CO}_{2}$. Ph.D. Dissertation, Universidade Nova de Lisboa-Faculdade de Ciências e Tecnologia, Caparika, Portugal, 2018.

40. Cruz-Martínez, F.; Buchaca, M.M.S.; Martínez, J.; Fernández-Baeza, J.; Sánchez-Barba, L.F.; Rodríguez-Diéguez, A.; Castro-Osma, J.A.; Lara-Sánchez, A. Synthesis of Bio-Derived Cyclic Carbonates from Renewable Resources. ACS Sustain. Chem. Eng. 2019, 7 , 20126-20138. [CrossRef]

41. Aomchad, V.; Cristòfol, A.; Monica, F.D.; Limburg, B.; D’Elia, V.; Kleij, A.W. Recent progress in the catalytic transformation of carbon dioxide into biosourced organic carbonates. Green Chem. 2021, 23, 1077-1113. [CrossRef] 
42. Rehman, A.; Saleem, F.; Javed, F.; Ikhlaq, A.; Ahmad, S.W.; Harvey, A. Recent advances in the synthesis of cyclic carbonates via $\mathrm{CO}_{2}$ cycloaddition to epoxides. J. Environ. Chem. Eng. 2021, 9, 105113. [CrossRef]

43. Fiorani, G.; Stuck, M.; Martin, C.; Belmonte, M.M.; Martin, E.; Escudero-Adan, E.C.; Kleij, A.W. Catalytic Coupling of Carbon Dioxide with Terpene Scaffolds: Access to Challenging Bio-Based Organic Carbonates. Chem. Sus. Chem. 2016, 9, $1304-1311$. [CrossRef]

44. Rehman, A.; Fernández, A.M.L.; Resul, M.F.M.G.; Harvey, A.P. Highly selective, sustainable synthesis of limonene cyclic carbonate from bio-based limonene oxide and $\mathrm{CO}_{2}$ : A kinetic study. J. CO2 Util. 2019, 29, 126-133. [CrossRef]

45. Khotimchenko, Y.S.; Kovalev, V.V.; Savchenko, O.V.; Ziganshina, O.A. Physical-Chemical Properties, Physiological Activity, and Usage of Alginates, the Polysaccharides of Brown Algae. Russ. J. Mar. Biol. 2001, 27, 53-64. [CrossRef]

46. Kopylovich, M.N.; Guedes da Silva, M.F.C.; Martins, L.M.D.R.S.; Mahmudov, K.T.; Pombeiro, A.J.L. Synthesis, structure and electrochemical behaviour of $\mathrm{Na}, \mathrm{MgII}, \mathrm{MnII}, \mathrm{ZnII}, \mathrm{CdII}$ and NiII complexes of 3-(2-carboxyphenylhydrazone)pentane-2,4-dione. Polyhedron 2013, 50, 374-382. [CrossRef]

47. Kopylovich, M.N.; Leod, T.C.O.M.; Mahmudov, K.T.; Guedes da Silva, M.F.C.; Pombeiro, A.J.L. Zinc(II) ortho-hydroxyphenylhydrazo$\beta$-diketonate complexes and their catalytic ability towards diastereoselective nitroaldol (Henry) reaction. Dalton Trans. 2011, 40, 5352-5361. [CrossRef] [PubMed]

48. Mustapa, A.N.; Martin, Á.; Sanz-Moral, L.M.; Rueda, M.; Cocero, M.J. Impregnation of medicinal plant phytochemical compounds into silica and alginate aerogels. J. Supercrit. Fluids 2016, 116, 251-263. [CrossRef]

49. Naz, G.; Othaman, Z.; Shamsuddin, M.; Ghoshal, S.K. Aliquat 336 stabilized multi-faceted gold nanoparticles with minimal ligand density. Appl. Surf. Sci. 2016, 363, 74-82. [CrossRef]

50. Patel, R.P.; Purohit, N.S.; Suthar, A.M. An overview of silica aerogels. Int. J. Chemtech Res. 2009, 1, $1052-1057$.

51. Fan, L.; Du, Y.; Wang, X.; Huang, R.; Zhang, L.; Hu, L. Preparation and characterization of alginate/poly(vinyl alcohol) blend fibers. J. Macromol. Sci. Pure Appl. Chem. 2005, 42, 41-50.

52. Yang, G.; Zhang, L.; Penga, T.; Zhong, W. Effects of $\mathrm{Ca}^{2+}$ bridge cross-linking on structure and pervaporation of cellulose/alginate blend membranes. J. Membr. Sci. 2000, 175, 53-60. [CrossRef]

53. Montoya, C.A.; Paninho, A.B.; Felix, P.M.; Zakrzewska, M.E.; Vital, J.; Najdanovic-Visak, V.; Nunes, A.V.M. Styrene carbonate synthesis from $\mathrm{CO}_{2}$ using tetrabutylammonium bromide as a non-supported heterogeneous catalyst phase. J. Supercrit. Fluids 2015, 100, 155-159. [CrossRef]

54. Montoya, C.A.; Gómez, C.F.; Paninho, A.B.; Nunes, A.V.M.; Mahmudov, K.T.; Najdanovic-Visak, V.; Martins, L.M.D.R.S.; Guedes da Silva, M.F.C.; Nunes da Ponte, M.; Pombeiro, A.J.L. Cyclic carbonate synthesis from $\mathrm{CO}_{2}$ and epoxides using zinc(II) complexes of arylhydrazones of $\beta$-diketones. J. Catal. 2016, 335, 135-140. [CrossRef]

55. Novak, Z.; Knez, Ž. Diffusion of methanol-liquid $\mathrm{CO}_{2}$ and methanol-supercritical $\mathrm{CO}_{2}$ in silica aerogels. J. Non Cryst. Solids 1997, 221, 163-169. [CrossRef]

56. Smirnova, I.; Arlt, W. Synthesis of silica aerogels: Influence of the supercritical CO2 on the Sol-Gel process. J. Solgel Sci. Techn. 2003, 28, 175-184. [CrossRef]

57. Valentin, R.; Horga, R.; Bonelli, B.; Garrone, E.; Renzo, F.D.; Quignard, F. Acidity of alginate aerogels studied by FTIR spectroscopy of probe molecules. Macromol. Symp. 2005, 230, 71-77. [CrossRef]

58. Mehling, T.; Smirnova, I.; Guenther, U.; Neubert, R.H.H. Polysaccharide-based aerogels as drug carriers. J. Non Cryst. Solids 2009, 355, 2472-2479. [CrossRef]

59. Sanz-Moral, L.M.; Rueda, M.; Nieto, A.; Novak, Z.; Knez, Ž.; Martín, Á. Gradual hydrophobic surface functionalization of dry silica aerogels by reaction with silane precursors dissolved in supercritical carbon dioxide. J. Supercrit. Fluids 2013, 84, 74-79. [CrossRef]

60. Carrodeguas, L.P.; González-Fabra, J.; Castro-Gómez, F.; Bo, C.; Kleij, A.W. AlIII-catalysed formation of poly(limonene)carbonate: DFT analysis of the origin of stereoregularity. Chem. Eur. J. 2015, 21, 6115-6124. 